\title{
Significance of bacterial and white cell counts in midstream urines
}

\author{
PJ LITTLE, BARBARA A PEDDIE, AND ADRIENNE R SINCOCK \\ From the Department of Renal Medicine, Christchurch Hospital, Christchurch, New Zealand
}

SUMMARY The results of cultures carried out on urine collected by a midstream technique (MSU) have been compared with the results of cultures of urine collected by suprapubic bladder aspiration (SPA) in the same 903 patients. Comparisons indicate that when there are more than $100 \times 10^{6} / 1$ $(100000 / \mathrm{ml}) \mathrm{Gram}$-negative bacteria in the midstream urine this finding is confirmed by suprapubic aspiration in $92 \%$ of patients, and in $70 \%$ when the urine contained this number of Gram-positive bacteria. When the culture contained more than one species (mixed organisms), the presence of infection was confirmed in only $11 \%$. When there were $10-100 \times 10^{6} / 1$ bacteria in the MSU the finding of Gram-negative bacilli still indicated urinary infection in $74 \%$ of patients, but the presence of Gram-positive organisms was confirmed in only $30 \%$ and mixed organisms in $2 \%$. In asymptomatic patients, the presence of white cells in the urine was not helpful in confirming the diagnosis of infection. The nature of the organism found in the MSU is almost as important as the number of bacteria in assessing the validity of the result.

The results of urine cultures performed on urine collected by a midstream technique are often misleading in that in some patients heavy contamination may occur. Kass ${ }^{1}$ provided statistical analyses of multiple midstream urines (MSUs) to establish the criteria separating contamination from true infection. $\mathrm{He}$ found the presence of a concentration of organisms greater than $100 \times 10^{6} / 1(>100000 / \mathrm{ml})$ could be regarded as indicating urinary infection, but when the counts were less than $100 \times 10^{6} / 1$ repeat specimens were rarely alike. ${ }^{2} \mathrm{He}$ showed that the finding of greater than $100 \times 10^{6}$ organisms per litre $(>100000$ per $\mathrm{ml})$ of urine is reproducible on $80 \%$ of occasions and that it may therefore be assumed that on $20 \%$ of occasions it does not represent true infection of the urinary tract. ${ }^{3}$ Although the technique of suprapubic bladder aspiration (SPA) gives a more accurate result, this method is often inconvenient and difficult to those not familiar with its use. In this paper an attempt is made to correlate the results of urine examinations using the two techniques so that a more accurate estimate can be made of the significance of the result of examination of an MSU. The results were assessed with

Received for publication 4 April 1979 particular reference to the identity of the organisms present in the urine.

\section{Method}

In this study SPA was carried out in 903 women, and the result was compared with a preceding MSU examination. The patients were 840 asymptomatic women examined at the first attendance at an antenatal clinic, 53 asymptomatic student nurses, and 10 women presenting with symptomatic urinary tract infection (UTI). All the patients had an initial MSU containing $\geqslant 10 \times 10^{6} / 1$ organisms $(\geqslant 10000 / \mathrm{ml})$.

The MSU was collected by a nurse employed for this purpose. Perineal cleansing with sterile water preceded collection. SPA was carried out within seven days of the MSU by a method previously described. ${ }^{4}$ All urine cultures were carried out on the day of urine collection. Bacterial counts were made by pour plate dilution technique. ${ }^{5}$

Urinary white cell counts (WCC) were made on 462 of the urine samples collected by MSU and on 37 of those collected by SPA.6,7 An upper limit of 10 cells $\times 10^{6} / 1(10 / \mathrm{cmm})$ in uncentrifuged urine was used in this study. ${ }^{8}$ No limits of normality of 
Table 1 Result of suprapubic aspiration (SPA) after a midstream urine (MSU) containing 10-100 × 106/l bacteria $(10000-100000 / \mathrm{ml})$

\begin{tabular}{lccc}
\hline Organism & $\begin{array}{l}\text { MSU } \\
\text { (No. tested) }\end{array}$ & \multicolumn{2}{l}{$S P A$} \\
\cline { 3 - 4 } & & No. infected & $\%$ \\
\hline E. coli & 28 & 21 & 75 \\
Klebsiella and Enterobacter spp & 2 & 2 & \\
Proteus mirabilis & 5 & 3 & 25 \\
Staphylococcus spp & 36 & 9 & 36 \\
Streptococcus spp & 11 & 4 & 2 \\
Mixed & 100 & 2 & 23 \\
Total & 182 & 41 & \\
\hline
\end{tabular}

WCC in urine collected by SPA are available. The technique used requires the administration of a diuretic and forced fluid intake so that considerable dilution of urine occurs.

\section{Results}

The results of SPAs done on patients with $10-100 \times 10^{6} / 1(10000-100000 / \mathrm{ml})$ bacteria in the initial MSU are shown in Table 1. Infection was confirmed in 26 of 35 patients with 10-100 $\times 10^{6} / 1$ Gram-negative bacilli in the MSU. Where the MSU had 10-100 $\times 10^{6} / 1$ Gram-positive organisms, 13 out of 47 bladder urines were found to be infected. Only two of 100 urines with mixed cultures of $10-100 \times 10^{6} / 1$ bacteria in the MSU had infected SPAs.

Table 2 shows the results of the SPA when the MSU showed $>100 \times 10^{6} / 1(>100000 / \mathrm{ml})$ bacteria. This demonstrates that where the initial MSU had $100 \times 10^{6} / 1$ of a pure growth of Escherichia coli, Proteus spp, Klebsiella spp, or Enterobacter spp, $92 \%$ of the SPAs were infected. With $>100 \times 10^{6} / 1$ streptococci in the MSU $81 \%$ of SPAs were infected, and with $>100 \times 10^{6} / 1$ staphylococci $67 \%$ were infected. Where the initial MSU had a mixed culture of $>100 \times 10^{6} / 1$ bacteria only $11 \%$ of the bladder

Table 2 Result of suprapubic aspiration (SPA) after a midstream urine $(\mathrm{MSU})$ containing $>100 \times 10^{6} / \mathrm{l}$ bacteria $(>100000 / \mathrm{ml})$

\begin{tabular}{llll}
\hline Organism & $\begin{array}{l}\text { MSU } \\
(\text { No. tested })\end{array}$ & \multicolumn{2}{l}{$S P A$} \\
\cline { 3 - 4 } & & No. infected & $\%$ \\
\hline E. coli & 399 & 370 & 93 \\
Klebsiella and Enterobacter spp & 12 & 11 & 92 \\
Proteus mirabilis & 26 & 24 & 92 \\
Staphylococcus spp & 75 & 50 & 67 \\
Streptococcus spp & 31 & 25 & 81 \\
Mixed & 146 & $16^{*}$ & 11 \\
Total & 689 & 496 & 72 \\
\end{tabular}

* One had true mixed infection with two bacterial species present in SPA; 15 had only one species present in SPA.
Table 3 Result of white cell concentration (WCC) on initial midstream urine (MSU) compared with bacterial count of MSU and suprapubic aspiration (SPA)

\begin{tabular}{lcccc}
\hline $\begin{array}{l}\text { MSU } \\
\text { bacterial count }\end{array}$ & $\begin{array}{l}\text { Infected } \\
\text { WCC } \times 10 \% / l\end{array}$ & \multicolumn{2}{l}{$\begin{array}{l}\text { Not infected } \\
\text { WCC } \times 10^{*} / l\end{array}$} \\
\cline { 2 - 5 }$\left(\times 10^{\circ} / l\right)$ & $\leqslant 10$ & $>10$ & $\leqslant 10$ & $>10$ \\
\hline $10-100$ & 13 & 11 & 8 & 13 \\
100 & 241 & 130 & 27 & 20 \\
\hline
\end{tabular}

Note: Bacterial counts $100 \times 10^{8} / 1$ (SI units) $=100000 / \mathrm{ml}$ WCC $10 \times 10^{\circ} / 1$ (SI units) $=10 / \mathrm{cmm}$

urines were infected. In only one specimen was a true mixed infection found.

Table 3 shows the WCC of the initial MSU together with the result of culture of the SPA. When the initial MSU had $>100 \times 10^{6} / 1$ organisms, the WCC was raised in $65 \%$ of those in whom infection was confirmed and in $57 \%$ of those in whom the SPA was sterile. There were also 130 patients $(35 \%)$ with infected SPAs but no raised WCC. In a further group of 37 patients, a sterile initial MSU was accompanied by a raised WCC. This finding was confirmed by SPA in 13, while 24 had a normal white cell concentration.

\section{Discussion}

$\mathrm{Kass}^{9}$ introduced the concept of quantitative urine cultures to enable the diagnosis of urinary tract infection in symptomatic and asymptomatic patients to be made with more accuracy. Since then, a concentration of organisms exceeding $100 \times 10^{6} / 1$ in an MSU has been taken to indicate infection. In asymptomatic pregnant women, a count of $>100 \times 10^{6} / 1$ was reproducible on $80 \%$ of occasions. ${ }^{3}$ Kass $^{1}$ also showed that if urine contained less than $10 \times 10^{6} / 1(10000 / \mathrm{ml})$ bacteria then this represented contamination. The results presented here indicate that knowledge of the identity of organisms in the urine may help in assessing the probability of the presence of a true infection. Infection was confirmed by SPA for $72 \%$ of all patients with MSU > $100 \times 10^{6} / 1$ bacteria. When MSUs with $>100 \times 10^{6} / 1$ mixed organisms were excluded SPAs confirmed infection in $88 \%$ of cases.

The technique of SPA is the simplest way to establish with certainty whether or not bacteria are present within the urinary tract. ${ }^{4}$ However, it is not always possible or desirable to take a bladder aspirate before starting treatment for symptomatic UTI. Only one-half of patients presenting with the symptoms generally suggestive of UTI will be found to have bacterial infection, and it is probable that those without infection should be dealt with differently 
from those with infection. ${ }^{10,11}$ The interpretation of the initial culture of urine collected by the MSU technique is therefore important. Moreover, when an MSU is part of a routine examination, it is desirable to know the significance of an equivocal result in an asymptomatic patient.

When the MSU has $10-100 \times 10^{6}$ organisms/l, the results of SPAs are very different with different species of bacteria. If a mixed growth is obtained from an MSU at counts below $100 \times 10^{6}$ organisms/l the probability that SPA will confirm the presence of organisms is very low. When a pure culture of Gram-positive cocci at this concentration is obtained in an MSU one-third can be confirmed by SPA. However, when a pure growth of Gramnegative bacilli is obtained this may be confirmed by SPA even at counts as low as $10 \times 10^{6} / 1$. When the number of organisms in an MSU is above $100 \times 10^{6} / 1$ infection is likely to be confirmed except when there is a mixed growth. It is of interest that in only one of the 903 SPAs was a true mixed infection found. The probability that a culture result indicates true infection should be taken into account when carrying out sensitivity testing of isolated organisms and also when initiating or assessing the results of treatment. It has been assumed throughout that if the MSU contains less than $10 \times 10^{6} / 1$ bacteria then infection is very unlikely and SPA is unnecessary.

The WCC was not a useful diagnostic aid to confirm the presence or absence of UTI. It should be emphasised that most of these patients were asymptomatic and therefore not clinically comparable with patients with symptomatic UTI.

From this study it is concluded that the nature of the organism found in the urine is almost as important as the concentration of bacteria in assessing whether or not true urinary infection is present.

\section{References}

${ }^{1}$ Kass E H. Asymptomatic infections of the urinary tract. Trans Assoc Am Physicians 1956; 69: 56-64.

${ }^{2} \mathrm{Kass} \mathrm{E} \mathrm{H}$. Bacteriuria and the diagnosis of infections of the urinary tract. Arch Intern Med 1957; 100: 709714.

${ }^{3}$ Kass H E. Pyelonephritis and bacteriuria. A major problem in preventive medicine. Ann Intern Med 1962; 56: 46-53.

${ }^{4}$ Bailey R R, Little P J. Suprapubic bladder aspiration. In: Kincaid-Smith P, Fairley K F, eds. Renal Infection and Renal Scarring: Proceedings of an International Symposium on Pylonephritis, Vesico-ureteric Reflux and Renal Papillary Necrosis. Melbourne, Australia: Mercedes. 1971: 81-84.

${ }^{5}$ Mackie T J, McCartney J E. Handbook of Bacteriology. 10th ed. Cruickshank R, ed. Edinburgh: Livingstone. 1960: 303.

${ }^{6}$ Little P J. Urinary white-cell excretion. Lancet 1962; 1: 1149-1151.

${ }^{7}$ Little P J. Diagnostic criteria of pyelonephritis. J Clin Pathol 1965; 18: 556-558.

${ }^{8}$ Little P J. A comparison of the urinary white cell concentration and the white cell excretion rate. Br J Urol 1964; 36: 360-363.

${ }^{9} \mathrm{Kass} \mathrm{E} \mathrm{H}$. Chemotherapeutic and antibiotic drugs in the management of infections of the urinary tract. Am J Med 1955; 18: 764-781.

${ }^{10}$ Tapsall J W, Bell S M, Taylor P C, Smith D D. Relevance of 'significant bacteriuria' to aetiology and diagnosis of urinary-tract infection. Lancet 1975; 2: 637-639.

${ }^{11}$ Peddie B A, Little P J, Sincock A R. Urinary tract infection in general practice. $N Z$ med $J$ 1978; 88: 317-320.

Requests for reprints to: Dr PJ Little, Department of Renal Medicine, Riyadh Military Hospital, PO Box 7897, Riyadh, Saudi Arabia. 